\title{
MBL2 Gene Polymorphism and the Association with Neonatal Sepsis in Egyptian Neonates, a Case Control Study
}

\author{
Ghada El-Saeed Mashaly1* , Amr Mohamed El-Sabbagh'1, Samah Sabry El-Kazzaz1, \\ Islam Nour ${ }^{2}$ \\ ${ }^{1}$ Medical Microbiology and Immunology Department, Faculty of Medicine, Mansoura University, Mansoura, \\ Egypt \\ ${ }^{2}$ Neonatal Intensive Care Unit, Faculty of Medicine, Mansoura University, Mansoura, Egypt \\ Email: "ghadamashaly@yahoo.com
}

Received 14 June 2016; accepted 25 September 2016; published 28 September 2016

Copyright (C) 2016 by authors and Scientific Research Publishing Inc.

This work is licensed under the Creative Commons Attribution International License (CC BY).

http://creativecommons.org/licenses/by/4.0/

(c) (i) Open Access

\begin{abstract}
Mannose binding lectin (MBL) is an important component of innate immunity particularly in neonates whose adaptive immunity is not fully developed. Polymorphism in MBL2 gene promoter and exon1 determines MBL serum level and function. The aim of this study was to investigate the frequency of different $M B L 2$ genotypes in neonatal sepsis among patients of neonatal intensive care unit (NICU). Two hundred and forty-five neonates were enrolled in this study (127 infected and 118 uninfected controls). Multiplex PCR and double amplification refractory mutation system (dARMS) were used for typing of $M B L 2$ exon1 and promoter respectively. Klebsiella species were the most frequently isolated organisms $(22.8 \%)$. There is no statistical significance difference in the distribution of different expression genotypes between infected group and controls $(P=0.11)$. However, prevalence of low MBL2 expression genotypes (XA/0 and 0/0) was higher in infected patients compared to control group (patients $25.2 \%$ and controls $15.3 \%$ ). Low and medium $M B L 2$ expression genotypes were mostly associated with Gram-negative bacterial infections $(18.9 \%$ and $\mathbf{2 2 . 8 \% )}$ respectively. A statistically significant association of Gram-negative bacterial infections with low MBL2 expression genotypes was found $(P=0.02)$. Higher frequency of $A B$ and $B B$ genotypes was observed (31.5\% and $7.9 \%$ ) in patients group compared to control, but without statistical significant difference.
\end{abstract}

\section{Keywords}

Mannose Binding Lectin (MBL), Neonatal Sepsis, Gene Polymorphism, Multiplex PCR, Geneotype, Haplotype

\footnotetext{
${ }^{*}$ Corresponding author.
}

How to cite this paper: Mashaly, G.E.-S., El-Sabbagh, A.M., El-Kazzaz, S.S. and Nour, I. (2016) MBL2 Gene Polymorphism and the Association with Neonatal Sepsis in Egyptian Neonates, a Case Control Study. Open Journal of Immunology, 6, 111119. http://dx.doi.org/10.4236/oji.2016.63012 


\section{Introduction}

Neonatal immunity depends mainly on the innate immune system. Complement factors and acute phase proteins, are important immune system mediators. They are critically important to prevent infections [1].

Mannose binding lectin (MBL) is a serum protein, produced by liver and involved in innate immunity. It binds to residues on the surface of pathogenic micro-organisms. This results in complement activation and antigens opsonization [2].

Variations of MBL plasma levels are affected by single nucleotide polymorphisms (SNPs) at promoter and coding segment of $M B L 2$ gene [3].

MBL2 gene is located on chromosome 10 in the region 10q21-24. The coding segment is composed of four exons. Three functional polymorphisms in exon 1 affect the production of MBL. The common non mutated MBL allele is named A, while the three variant alleles namely " $B$ ” (codon 54), "C" (codon 57) and "D” (codon 52) are designated as “O” allele [4].

It has been proposed that the presence of the $\mathrm{O}$ allele weakens the oligomerization of MBL, resulting in diminished levels of functional protein circulating in the serum [5].

Furthermore, SNPs in the promoter region at positions -550 and -221 , known as variations $\mathrm{H} / \mathrm{L}$ and $\mathrm{X} / \mathrm{Y}$ respectively, also affect $M B L 2$ expression, although only the X variant significantly reduces MBL serum levels [5] [6].

Subsequently, the combination of the genetic variation into both exon 1 and promoter results in 3 MBL genotype expression profiles, which are associated with high (YA/YA, YA/XA), medium (XA/XA, YA/O), and low (XA/O, O/O) MBL serum levels [5]-[7].

The low MBL expression genotypes (XA/O and O/O) [5] [8], have been associated with a decreased ability of opsonization of microorganisms and an increased susceptibility to infections, mainly in early childhood and in immunocompromised individuals [9] [10].

Present study was designed to investigate the possible role of polymorphisms of $M B L 2$ gene on the risk of neonatal infections among Egyptian neonates admitted to NICU in Mansoura University Children Hospital.

\section{Subject and Method}

The study was performed during period extending from January 2013 to August 2015, to investigate infection among neonates admitted to Neonatal Intensive Care Unit (NICU) of Mansoura University Children Hospital. Neonatal infection was diagnosed based on the presence of clinical and microbiological data. The included neonates should have any of the following physical signs: (1) respiratory dysfunction (retractions, grunting, apnea, tachypnea, cyanosis); (2) circulatory dysfunction (tachycardia, bradycardia, delayed capillary refill, hypotension); (3) temperature instability; (4) feeding intolerance; (5) neurologic (lethargy, fits); (6) glucose intolerance [11]. A positive blood culture was required to verify cases with blood stream infection. Pneumonia was defined according to the CDC criteria [12]. Neonates who had no clinical and laboratory signs of infection until discharge were considered as control group. One hundred and twenty-seven infected neonates and 118 uninfected neonates were enrolled in this study.

For all cases and controls, $2 \mathrm{ml}$ blood in EDTA was collected for molecular analysis. In cases of a suspected infection, cultures were performed according to suspected site of infection.

The study protocol was approved by the local medical ethics committee in faculty of medicine, Mansoura University.

Coagulase-negative Staphylococci was reported only when it was detected in two; simultaneously withdrawn; blood culture specimens, together with coexistence of physical signs and laboratory features of sepsis.

\subsection{Molecular Techniques}

Genomic DNA was extracted from stored blood using QIAamp DNA isolation kit (QIAGEN) according to manufacturer's instructions.

MBL2 gene promoter polymorphisms (-550 H/L and -221 Y/X) and exon1 polymorphisms (52, 54 and 57) were typed by double amplification refractory system (dARMS) and multiplex PCR respectively according to protocol described previously [13].

The primer sequences for the promoter genotyping and codon polymorphism are described in Table 1 . 
Table 1. PCR primers and products of different $M B L 2$ haplotypes/genotypes.

\begin{tabular}{|c|c|c|c|c|}
\hline $\begin{array}{c}\text { Gene } \\
\text { region }\end{array}$ & $\begin{array}{l}\text { Reaction } \\
\text { No. }\end{array}$ & Primers & $\begin{array}{l}\text { Different haplotypes/ } \\
\text { genotypes }\end{array}$ & PCR product lengths \\
\hline \multirow{3}{*}{ Promoter } & 1 & $\begin{array}{c}\text { L: 5'CTTACCCAGGCAAGCCGGTC3' } \\
+ \\
\text { X: 5'GCTGTCTACAAATATCAGAAGGTC3' }\end{array}$ & LX haplotype & \multirow{3}{*}{373 bp } \\
\hline & 2 & $\begin{array}{c}\text { L: 5'CTTACCCAGGCAAGCCGGTC3' } \\
++ \\
\text { Y: 5'CCTGTCTACAAATATCAGAAGGTC 3' }\end{array}$ & LY haplotype & \\
\hline & 3 & $\begin{array}{c}\text { H: 5'CTTACCCAGGCAAGCCGGTG3' } \\
+ \\
\text { Y: 5'CCTGTCTACAAATATCAGAAGGTC 3' }\end{array}$ & HY haplotype & \\
\hline \multirow{11}{*}{$1^{\text {st }}$ exon } & \multirow{7}{*}{4} & \multirow{7}{*}{$\begin{array}{l}\text { CF: 5' GCAGCGTCTTACTCAGAAACTGTG3' } \\
\text { + CR: 3'GGGCTGGCAAGACAACTATTAGTC5' } \\
\text { + 52R-D: 3'ACAGTACCGTGGTTCCCTCT5' } \\
\text { + 54R-B: 3'TGTTGTTCCCTCTTTTCCCC5' } \\
\text { + 57R-C: 3'TTCGTTTCCCCCTTGGTCG5' }\end{array}$} & $\mathrm{D} / \mathrm{A}$ or $\mathrm{D} / \mathrm{D}$ & $128+339 b p$ \\
\hline & & & $\mathrm{B} / \mathrm{A}$ or $\mathrm{B} / \mathrm{B}$ & $135+339$ bp \\
\hline & & & $\mathrm{C} / \mathrm{A}$ or $\mathrm{C} / \mathrm{C}$ & $143+339$ bp \\
\hline & & & D/B genotype & $128+135+339 b p$ \\
\hline & & & D/C genotype & $128+143+339$ bp \\
\hline & & & B/C genotype & $135+143+339 b p$ \\
\hline & & & A/A genotype & 339 \\
\hline & \multirow{4}{*}{5} & \multirow{4}{*}{$\begin{array}{l}\text { CF + CR + } \\
\text { 52R-ABC: 3'GCAGTACCGTGGTTCCCTCT5' } \\
\text { + 54R-ACD: 3' CGTTGTTCCCTCTTTCCCC5' } \\
\text { + 57R-ABD: 3'CTCGTTTCCCCCTTGGTCG5' }\end{array}$} & D/D genotype & $135+143+339$ bp \\
\hline & & & B/B genotype & $128+143+339 b p$ \\
\hline & & & C/C genotype & $128+135+339$ bp \\
\hline & & & $\begin{array}{l}\mathrm{A} / \mathrm{A}, \mathrm{A} / \mathrm{B}, \mathrm{A} / \mathrm{C} \text { or } \\
\text { A/D genotype }\end{array}$ & $128+135+143+339 b p$ \\
\hline
\end{tabular}

\subsection{PCR Reactions}

PCRs reactions were performed as described previously. Briefly, all reactions were initiated by a denaturation step at $95^{\circ} \mathrm{C}$ for $3 \mathrm{~min}$, followed by 40 cycles of $30 \mathrm{~s}$ at $95^{\circ} \mathrm{C}, 30 \mathrm{~s}$ at $62^{\circ} \mathrm{C}$, and $30 \mathrm{~s}$ (in the case of the $1 \mathrm{st}$ exon analysis) to $60 \mathrm{~s} \mathrm{(in} \mathrm{case} \mathrm{of} \mathrm{the} \mathrm{promoter} \mathrm{genotyping)} \mathrm{at} 72^{\circ} \mathrm{C}$. Reactions were completed by an extension step at $72^{\circ} \mathrm{C}$ for $7 \mathrm{~min}$.

PCR products specific for the particular promoter polymorphisms and the $1^{\text {st }}$ exon alleles were detected by electrophoresis in $2 \%$ agarose or in $4 \%$ MetaPhor agarose, respectively. The gels were stained with ethidium bromide and visualized with UV light.

\subsection{Statistical Analysis}

Statistical analysis was computed on Statistical Package for Social Sciences (SPSS, version 16.00; Chicago, IL, USA). Descriptive statistics were described as mean, standard deviation (s.d), minimum, maximum and percentage. Categorical variables were analyzed using Chi-square test $\left(\chi^{2}\right)$ or Fisher exact test. High $M B L 2$ expression genotypes were considered as reference group. Kolmogorov-Smirnov test was used to assess normality of continuous variables. Skewed data were analyzed with nonparametric methods (Mann-Whitney test). Values of P < 0.05 were considered to be significant.

\section{Results}

One hundred and twenty-seven infected neonates and 118 uninfected controls were included in this study. Within the infected group, the mean gestational age was $33.7 \mathrm{wk}$ (range: 27 - $39 \mathrm{wk}$ ). The mean gestational age of the control group was $35.3 \mathrm{wk}$ (rang: 28 - 39). Characteristics and clinical diagnosis at admission of patients and control groups are shown in Table 2. 
Table 2. Demographic features and clinical diagnosis of patients and control groups.

\begin{tabular}{|c|c|c|c|}
\hline & $\begin{array}{c}\text { Patients (number = 127) } \\
\text { n (\%) }\end{array}$ & $\begin{array}{c}\text { Control (number = 118) } \\
\text { n (\%) }\end{array}$ & P value \\
\hline \multicolumn{4}{|l|}{ Sex } \\
\hline Male No (\%) & $62(48.8)$ & $56(47.5)$ & $0.8^{\mathrm{a}}$ \\
\hline Female No (\%) & $65(51.2)$ & $62(52.5)$ & \\
\hline \multicolumn{4}{|l|}{ Gestational age } \\
\hline Mean \pm SD (min - max) & $33.7 \pm 4.1(27-39)$ & $35.3 \pm 2.6(28-39)$ & $0.04^{\mathrm{b}}$ \\
\hline \multicolumn{4}{|l|}{ Prematurity (<37 wk) } \\
\hline $\mathrm{N}(\%)$ & $77(60.6 \%)$ & $51(43.2)$ & $0.006^{\mathrm{c}}$ \\
\hline \multicolumn{4}{|l|}{ Clinical diagnosis } \\
\hline Jaundice & 7 & 40 & \\
\hline Respiratory distress & 46 & 27 & \\
\hline Perinatal infection & 33 & 0 & \\
\hline Seizures & 12 & 0 & \\
\hline Perinatal asphyxia & 10 & 0 & \\
\hline Apnea of prematurity & 10 & 20 & \\
\hline Prematurity (for establishment of oral feeding) & 9 & 31 & \\
\hline
\end{tabular}

${ }^{\mathrm{a} C o m p a r i s o n}$ of the patients and control group regarding sex distribution; ${ }^{\mathrm{b} C o m p a r i s o n}$ of gestational age in the patients and control group; ${ }^{\mathrm{c} C o m p a-}$ rison of prematurity among patients and control group.

Infections detected were blood stream infection and pneumonia. A greater incidence of Gram-negative bacterial infections was detected (67.7\%). Klebsiella species were the main cause of both blood stream infection and pneumonia (22.8\%) as shown in Table 3.

The DNA samples of 245 neonates (127 infected cases and 118 controls) were analyzed. For each sample, four PCR reactions were done (three for promoter genotyping and one for the detection of mutant allele(s) of the exon 1; reaction No. 1-4 in Table 1). Another PCR reaction was carried out (reaction No. 5 in Table 1) if one mutant allele was detected within exon 1 . Regarding exon 1 polymorphism, we refer to the wild type allele as A and the $\mathrm{O}$ allele represents $\mathrm{D}, \mathrm{B}$, or $\mathrm{C}$ alleles [6] [14].

MBL2 promotor haplotypes and exon1 genotypes of the infected neonates and controls are compared in Table 4.

No significant difference in $M B L 2$ promoter haplotype distribution between patients and control groups $(\mathrm{P}=$ $0.8)$.

The AA genotype was less frequent in patients (47.2\%) than in control (56.8\%). Whereas, AO and OO genotypes were mostly present in infected groups (52.8\%) compared to controls (43.2\%). No statistical significant difference was found in distribution of (AA and AOIOO) genotypes between the two groups (P: 0.25).

After determination of $M B L 2$ promoter haplotype and exon 1 genotype, we reconstructed $M B L 2$ combined genotypes. Neonates (both patients and controls) were classified into three groups according to MBL expression levels, namely high (HYA/HYA, HYA/LYA, HYA/LXA, LYA/LYA, and LYA/LXA), medium producers (LXA/LXA, HYA/O, and LYA/O), and low producers (LXA/O and O/O). These combined genotypes were collected into six groups; high producers (YA/YA, YA/XA), medium producers (XA/XA, YA/O), and low producers (XA/O, and $\mathrm{O} / \mathrm{O})[5][6]$ as shown in Table 5 and Table 6.

$M B L 2$ deficient genotypes (XA/O or O/O) were detected in $25.2 \%$ of infected neonates and $15.3 \%$ of control group. No significant difference was found in the distribution of the three MBL2 expression groups between infected patients and the controls $(\mathrm{P}=0.11)$. Regarding the type of infection, low and medium MBL2 expression genotypes were mostly associated with Gram-negative bacterial infections (24/127 and 29/127 representing 18.9\% and 22.8\%) respectively. The incidence of Gram-negative bacterial infections was statistically significant higher in low $M B L 2$ genotypes than in high expression group $(\mathrm{P}=0.042)$.

Considering exon 1, heterozygous codon $54(\mathrm{AB})$ was the most frequent mutant in both infected and control groups (31.5\% and $28.8 \%$ respectively). Homozygous BB was detected in 7 cases and 5 controls. 
Table 3. Causative organisms of neonatal infections.

\begin{tabular}{|c|c|c|c|}
\hline & $\begin{array}{c}\text { Blood stream infection } \\
\text { (number }=90) \\
n(\%)\end{array}$ & $\begin{array}{c}\text { Pneumonia } \\
\text { (number }=37) \\
\text { n }(\%)\end{array}$ & $\begin{array}{c}\text { Total }=127 \\
\text { n (\%) }\end{array}$ \\
\hline Gram-negative bacteria & & & 86 (67.7) \\
\hline Klebsiella species & $22(24.4)$ & $7(18.9)$ & $29(22.8)$ \\
\hline E. coli & 15 (16.7) & $5(13.5)$ & $20(15.8)$ \\
\hline Acinetobacter species & $8(8.9)$ & $2(5.4)$ & $10(7.9)$ \\
\hline Enterobacter species & $14(15.6)$ & $1(2.7)$ & $15(11.8)$ \\
\hline Pseudomonas & $8(8.9)$ & $3(8.1)$ & $11(8.7)$ \\
\hline Proteus species & $1(1.1)$ & - & $1(0.8)$ \\
\hline Gram-positive bacteria & & & $41(32.3)$ \\
\hline Staphylococcus aureus & $12(13.3)$ & $14(37.8)$ & $26(20.5)$ \\
\hline Coagulase negative Staphylococci & $10(11.1)$ & 0 & $10(7.9)$ \\
\hline Streptococcus pneumonae & 0 & $5(13.5)$ & $5(3.9)$ \\
\hline
\end{tabular}

Table 4. MBL2 gene promotor haplotype, and exon 1 (A/O) genotypes in patients and control groups.

\begin{tabular}{|c|c|c|c|}
\hline & $\begin{array}{c}\text { Patients } \\
\text { (number = 127) }\end{array}$ & $\begin{array}{c}\text { Control } \\
(\text { number }=118)\end{array}$ & $P$ value \\
\hline \multicolumn{4}{|l|}{ MBL promoter haplotypes (n) } \\
\hline HY & 95 & 92 & \multirow{3}{*}{$0.8^{\mathrm{a}}$} \\
\hline LY & 119 & 112 & \\
\hline LX & 40 & 32 & \\
\hline MBL exon 1 (A/O) genotypes, n (\%) & & & $0.25^{\mathrm{b}}$ \\
\hline AA & $60(47.2)$ & $67(56.8)$ & $0.17^{\mathrm{c}}$ \\
\hline AO & $53(41.7)$ & $43(36.4)$ & $0.43^{\mathrm{c}}$ \\
\hline $\mathrm{AB}$ & $40(31.5)$ & $34(28.8)$ & $0.75^{\mathrm{c}}$ \\
\hline $\mathrm{AD}$ & $12(9.4)$ & $9(7.6)$ & $0.65^{\mathrm{c}}$ \\
\hline $\mathrm{AC}$ & $1(0.8)$ & - & $0.43^{\mathrm{c}}$ \\
\hline OO & $14(11)$ & $8(6.8)$ & $0.27^{\mathrm{c}}$ \\
\hline $\mathrm{BB}$ & 10 (7.9) & $4(3.4)$ & $0.17^{\mathrm{c}}$ \\
\hline $\mathrm{BD}$ & $3(2.4)$ & $4(3.4)$ & $0.71^{\mathrm{c}}$ \\
\hline $\mathrm{DD}$ & $1(0.8)$ & - & $0.43^{\mathrm{c}}$ \\
\hline
\end{tabular}

${ }^{\mathrm{a} C}$ Comparison of $M B L 2$ promoter haplotypes distribution between patients and control groups; ${ }^{\mathrm{b}}$ Comparison of $M B L 2$ exon 1 (AA, AO, OO) genotypes distribution between patients and control groups; 'Comparison of MBL2 exon 1 (A, B, C, D) genotypes distribution between patients and control groups.

\section{Discussion}

Neonatal sepsis is an important cause of morbidity and mortality. Neonatal sepsis leads to poor neurodevelopmental outcomes especially in preterm [15]. MBL is an important serum protein involved in the innate immune response, as it is able to trigger complement activation [6]. MBL function is much important during the first month of life when the innate immunity is crucial. This to the degree that some researchers recommend MBL as one of biomarker panels for early detection of neonatal sepsis especially in low resource settings [16].

$M B L 2$ gene polymorphism plays an important role in determination of MBL level [7].

The present study describes MBL2 genotypes through analysis of the promoter region and exon 1 polymorphism, and comparing the distribution of the genotypes between infected neonates and uninfected control.

This is the first study to search in detailed MBL2 genotypes and susceptibility to infection in neonates in Egypt. 
Table 5. MBL2 genotypes grouped according to MBL predicted production in control and infected patients.

\begin{tabular}{ccccc}
\hline $\begin{array}{c}\text { MBL2 combined } \\
\text { genotypes }\end{array}$ & $\begin{array}{c}\text { Control } \\
\text { (number = 118) } \\
\mathbf{n}(\%)\end{array}$ & $\begin{array}{c}\text { Patients } \\
\text { (number = 127) } \\
\mathbf{n}(\%)\end{array}$ & $\begin{array}{c}\text { Patient with Gram negative } \\
\text { infection (number = 86) } \\
\text { n (\%) }\end{array}$ & $\begin{array}{c}\text { Patient with Gram positive } \\
\text { infection (number = 41) } \\
\text { n (\%) }\end{array}$ \\
\hline $\begin{array}{c}\text { High producer } \\
\text { YA\YA, YA\XA }\end{array}$ & $63(53.4)$ & $55(43.3)$ & $33(38.4)$ & $22(53.7)$ \\
$\begin{array}{c}\text { Medium producer } \\
\text { XA\XA, YAlO } \\
\text { Low producer } \\
\text { XA\O, O।O }\end{array}$ & $37(31.3)$ & $40(31.5)$ & $29(33.7)$ & $11(26.8)$ \\
\hline
\end{tabular}

Chi-square test was used for comparison of MBL2 genotypes between infected patients and control group: $\mathrm{P}^{\mathrm{a}}=0.11, \chi^{2}=4.3$; Comparing MBL2 genotypes in patients with Gram-negative bacterial infection to control group $\mathrm{P}^{\mathrm{b}}=\mathbf{0 . 0 4 2} ; \chi^{2}=6.3$; Comparing MBL2 genotypes in patients with Grampositive bacterial infection to control group $\mathrm{P}^{\mathrm{c}}=0.8 ; \chi^{2}=0.5$. Considering high MBL producer as reference group: Comparing patients (medium producers) with Gram-negative bacterial infection to control: $\mathrm{P}=0.3 ; \chi^{2}=1.1$; Comparing patients (low producers) with Gram-negative bacterial infection to control: $\mathrm{P}=\mathbf{0 . 0 2} ; \chi^{2}=5.3$; There is a significant association between low MBL genotypes and Gram negative bacterial infections.

Table 6. MBL2 combined genotypes in control and patients groups.

\begin{tabular}{|c|c|c|c|c|c|c|}
\hline $\begin{array}{l}\text { MBL2 combined } \\
\text { genotypes }\end{array}$ & $\begin{array}{c}\text { Control } \\
\text { (number = 118) } \\
\text { n (\%) }\end{array}$ & $\begin{array}{c}\text { Patients } \\
\text { (number = 127) } \\
\text { n (\%) }\end{array}$ & $\mathbf{P}^{1}$ & $\begin{array}{c}\text { Patient with } \\
\text { Gram-negative infection } \\
\text { (number = 86) } \\
\text { n (\%) }\end{array}$ & $\begin{array}{c}\text { Patient with } \\
\text { Gram-positive infection } \\
\text { (number = 41) } \\
\text { n (\%) }\end{array}$ & $\mathbf{P}^{2}$ \\
\hline \multicolumn{7}{|l|}{$\underline{\text { High producer }}$} \\
\hline \multicolumn{7}{|l|}{ YAIYA } \\
\hline HYA\HYA & $10(8.4)$ & $9(7.1)$ & 0.8 & $4(4.7)$ & $5(12.2)$ & 0.1 \\
\hline LYAILYA & $8(6.8)$ & $9(7.1)$ & 1 & $6(7)$ & $3(7.3)$ & 1 \\
\hline HYA LYA & $31(26.3)$ & 25 (19.7) & 0.2 & $15(17.4)$ & $10(24.3)$ & 0.5 \\
\hline \multicolumn{7}{|l|}{ YAIXA } \\
\hline LYA $\backslash L X A$ & $4(3.4)$ & $3(2.4)$ & 0.7 & $3(3.5)$ & 0 & 0.6 \\
\hline HYA $\backslash L X A$ & $10(8.5)$ & $9(7.1)$ & 0.8 & $5(5.8)$ & $4(9.7)$ & 0.5 \\
\hline \multicolumn{7}{|l|}{ Medium producer } \\
\hline \multicolumn{7}{|l|}{ XAIXA } \\
\hline LXA LXA & $4(3.4)$ & $5(3.9)$ & 1 & $5(5.8)$ & 0 & 0.2 \\
\hline \multicolumn{7}{|l|}{ YAIO } \\
\hline HYA\HYD & $2(1.7)$ & $3(2.4)$ & 1 & $3(3.5)$ & 0 & 0.6 \\
\hline HYA $\backslash L Y B$ & $16(13.6)$ & $23(18.1)$ & 0.3 & $13(15.1)$ & $10(24.4)$ & 0.3 \\
\hline HYA\LYC & 0 & $1(0.8)$ & 1 & $1(1.2)$ & 0 & 1 \\
\hline LYA\HYD & $3(2.5)$ & $1(0.8)$ & 0.4 & 0 & $1(2.4)$ & 1 \\
\hline LYA $\ Y B$ & $12(10.2)$ & $7(5.5)$ & 0.2 & $7(8.1)$ & 0 & 0.9 \\
\hline \multicolumn{7}{|l|}{ Low producer } \\
\hline \multicolumn{7}{|l|}{ XAlO } \\
\hline LXA $\$ LB & $6(5.1)$ & $10(7.9)$ & 0.4 & $5(5.8)$ & $5(12.2)$ & 0.3 \\
\hline LXA\HYD & $4(3.4)$ & $8(6.3)$ & 0.4 & $6(7)$ & $2(4.9)$ & 1 \\
\hline \multicolumn{7}{|l|}{$\mathrm{O} \ \mathrm{O}$} \\
\hline LYB \LYB & $4(3.4)$ & $10(7.9)$ & 0.2 & $9(10.5)$ & $1(2.4)$ & 0.2 \\
\hline$L Y B \backslash H Y D$ & $4(3.4)$ & $3(2.4)$ & 0.7 & $3(3.5)$ & - & 0.6 \\
\hline HYD $\backslash H Y D$ & 0 & $1(0.8)$ & 1 & $1(1.2)$ & - & 1 \\
\hline
\end{tabular}

Chi-square test and Fisher exact test were used as corresponding for comparison of MBL2 genotypes between infected patients and control; $\mathrm{P}^{1}$ comparison of combined genotypes between patients and control groups; $\mathrm{P}^{2}$ comparison of combined genotypes between patients with Gram-negative and patients with Gram-positive bacterial infections. 
In this study we use multiplex PCR which considered as a fast and inexpensive method for the detection of specific DNA sequences. These advantages are especially valuable when there is a need for analysis of a large number of samples and/ or various regions of the gene, which is the case of MBL2 genotyping.

In this study, the most common cause of culture proven neonatal sepsis was Klebsiella species. The rate of infections caused by Gram-positive like Staphylococcus aureus and coagulase negative Staphylococci in our study was much lower. This result is inconstant with many previous results [17]-[19] that reported Staphylococci as the most common cause of neonatal sepsis. However, many studies agreed with our result [20] [21]. This may be due to environmental differences and differences in the supportive care and infection control practices between different centers.

In our study, analysis of exon 1 mutant allele frequencies showed that $\mathrm{O}$ alleles ( $\mathrm{AO}$ and $\mathrm{OO}$ ) were mostly found in infected neonates (52\%), however this difference is not statistically significant. Allele B both heterozygous (AB) and homozygous (BB) was the commonest mutant allele encountered in neonatal sepsis (39.4\%). Similar results were obtained by Özkan et al., Dzwonek et al. and Roy et al. [22]-[24]. However, other studies like Ahrens et al. and Auriti et al. [25] [26] disagree with our result.

Considering combined MBL2genotypes, low MBL2 producing genotypes were more frequent in infected neonates compared to control group without statistical significant difference. This result somewhat agrees with the result obtained by Ozkan et al. [22] who found low producing MBL2 genotypes are significant risk factor for neonatal sepsis in Turkish neonates. Other studies like Frakking et al. [27] obtain different results, as they found no relation between the MBL2 gene polymorphism and neonatal sepsis. This discrepancy of results may be explained by different sample size and the variable distribution of $M B L 2$ genotyped in the study population. In addition to the different methods that were used for the diagnosis of neonatal sepsis in other studies.

MBL binds to the mannose-enriched portion of lipopolysaccharide of Gram-negative organisms through carbohydrate recognition domain (CRD) and its binding mediates lectin-complement pathway activation. Complement activation kills Gram-negative organisms either directly via the membrane-attack complex or by enhancing complement mediated phagocytosis through the increased deposition of opsonic C3 fragments [28] [29].

In this study, incidence of Gram-negative bacterial infections was statistically significant higher among patients expressing low-MBL-producing genotypes. Our results consistent with results obtained by Pehlivan et al. [30] which show that Gram-negative bacteremia was more common in deficient MBL2 AB/BB genotype. However our result inconsistent with study by Hellemann et al. [31] in critically ill patients admitted to an intensive care, which reported an association of low $M B L 2 \mathrm{O} / \mathrm{O}$ genotype with an increased incidence of Gram-positive infections. Other study performed by Klostergaard et al. [32] didn't find any association between MBL2 polymorphism and the type of bacterial sepsis. The diversity between the different studies may be explained by fact that MBL also acts as a scavenger molecule in maintaining internal tissue homeostasis. Apparent MBL associations may be due to disturbances in this scavenger system, rather than a direct anti-infectious effect [33].

Our study has some limitations. First we didn't investigate the other risk factors for neonatal infection. Also, we didn't measure the serum level of MBL as there is no consensus definition for the neonatal MBL deficiency. Lastly, our study didn't search the possible relation of preterm neonates with MBL2 polymorphism. So we recommend further studies to investigate the relation of low MBL producing genotypes to other risk factors for neonatal Gram-negative bacterial infection.

\section{Conclusion}

Low (LXA/O and O/O) and medium (XAIXA and YAIO) MBL producers are more frequently encountered in patients with neonatal sepsis than in control group. The low producing genotypes represent significant risk factor for developing Gram-negative bacterial infections in neonates.

\section{Conflict of Interests}

The authors declare that there is no conflict of interests regarding the publication of this paper.

\section{References}

[1] Strunk, T. and Burgner, D. (2006) Genetic Susceptibility to Neonatal Infection. Current Opinion in Infectious Diseases, 


\section{9, 259. http://dx.doi.org/10.1097/01.qco.0000224820.19858.7a}

[2] Neth, O., Jack, D.L., Dodds, A.W. and Holzel, H. (2000) Mannose-Binding Lectin Binds to a Range of Clinically Relevant Microorganisms and Promotes Complement Deposition. Infection and Immunity, 68, 688-693. http://dx.doi.org/10.1128/IAI.68.2.688-693.2000

[3] Monticielo, O.A., Mucenic, T., Xavier, R.M., Brenol, J.C. and Chies, J.A. (2008) The Role of Mannose Binding Lectin in Systemic Lupus Erythematosus. Clinical Rheumatology, 27, 413-419. http://dx.doi.org/10.1007/s10067-008-0838-8

[4] Garred, P., Larsen, F., Madsen, H.O. and Koch, C. (2003) Mannose-Binding Lectin Deficiency-Revisited. Molecular Immunology, 40, 73-84. http://dx.doi.org/10.1016/S0161-5890(03)00104-4

[5] Madsen, H.O., Garred, P., Thiel, S., Kurtzhals, J.A., Lamm, L.U., Ryder, L.P. and Svejgaard, A. (1995) Interplay between Promoter and Structural Gene Variants Control Basal Serum Level of Mannan-Binding Protein. Journal of Immunology, 155, 3013-3020.

[6] Turner, M.W. (2003) The Role of Mannose-Binding Lectin in Health and Disease. Molecular Immunology, 40, 423429. http://dx.doi.org/10.1016/S0161-5890(03)00155-X

[7] Frakking, F.N., Brouwer, N., Zweers, D., Merkus, M.P., Kuijpers, T.W., Offringa, M. and Dolman, K.M. (2006) High Prevalence of Mannose-Binding Lectin (MBL) Deficiency in Premature Neonates. Clinical \& Experimental Immunology, 145, 5-12. http://dx.doi.org/10.1111/j.1365-2249.2006.03093.x

[8] Garred, P., Madsen, H.O., Halberg, P., Petersen, J., Kronborg, A.S., Svejgaard, A., Andersen, V. and Jacobsen, S. (1999) Mannose-Binding Lectin Polymorphisms and Susceptibility to Infection in Systemic Lupus Erythematosus. Arthritis \& Rheumatology, 42, 2145-2152. http://dx.doi.org/10.1002/1529-0131(199910)42:10<2145::AID-ANR15>3.0.CO;2-\#

[9] Koch, A., Melbye, M., Sørensen, P., Homøe, P., Madsen, H.O., Mølbak, K., Hansen, C.H., Andersen, L.H., Hahn, G.W. and Garred, P. (2001) Acute Respiratory Tract Infections and Mannose-Binding Lectin Insufficiency during Early Childhood. JAMA, 285, 1316-1321. http://dx.doi.org/10.1001/jama.285.10.1316

[10] Summerfield, J.A., Sumiya, M., Levin, M. and Turner, M.W. (1997) Association of Mutations in Mannose Binding Protein Gene with Childhood Infection in Consecutive Hospital Series. BMJ, 314, 1229-1232. http://dx.doi.org/10.1136/bmj.314.7089.1229

[11] Haque, K.N. (2005) Definitions of Bloodstream Infection in the Newborn. Pediatric Critical Care Medicine, 6, S45S49. http://dx.doi.org/10.1097/01.pcc.0000161946.73305.0a

[12] Horan, T.C., Andrus, M. and Dudeck, M.A. (2008) CDC/NHSN Surveillance Definition of Health Care Associated Infection and Criteria for Specific Types of Infections in the Acute Care Setting. American Journal of Infection Control, 36, 309-332. http://dx.doi.org/10.1016/j.ajic.2008.03.002

[13] Skalnikova, H., Freiberger, T., Chumchalova, J., Grombirikova, H. and Sediva, A. (2004) Cost Effective Genotyping of Human MBL2 Gene Mutations Using Multiplex PCR. Journal of Immunological Methods, 295, 139-147. http://dx.doi.org/10.1016/j.jim.2004.10.007

[14] Garred, P., Larsen, F., Seyfarth, J., Fujita, R. and Madsen, H.O. (2006) Mannose-Binding Lectin and Its Genetic Variants. Genes \& Immunity, 7, 85-94. http://dx.doi.org/10.1038/sj.gene.6364283

[15] Mitha, A., Foix-L’Hélias, L., Arnaud, C., Marret, S., Vieux, R., Aujard, Y., Thiriez, G., Larroque, B., Cambonie, G., Burguet, A., Boileau, P., Rozé, J.C., Kaminski, M., Truffert, P. and Ancel, P.Y., EPIPAGE Study Group (2013) Neonatal Infection and 5-Year Neurodevelopmental Outcome of Very Preterm Infants. Pediatrics, 132, e372-e380. http://dx.doi.org/10.1542/peds.2012-3979

[16] Wagner, T.A., Gravett, C.A., Healy, S., Soma, V., Patterson, J.C., Gravett, M.G. and Rubens, C.E. (2011) Emerging Biomarkers for the Diagnosis of Severe Neonatal Infections Applicable to Lowresource Settings. Journal of Global Health, 1, 210-223.

[17] Chapagain, R.H., Acharya, R., Shrestha, N., Giri, B.R., Bagale, B.B. and Kayastha, M. (2015) Bacteriological Profile of Neonatal Sepsis in Neonatal Intermediate Care Unit of Central Paediatric Referral Hospital in Nepal. Journal of Nepal Health Research Council, 13, 205-208.

[18] Jiang, Y., Kuang, L., Wang, H., Li, L., Zhou, W. and Li, M. (2016) The Clinical Characteristics of Neonatal Sepsis Infection in Southwest China. Internal Medicine, 55, 597-603. http://dx.doi.org/10.2169/internalmedicine.55.3930

[19] Rohit, A., Maiti, B., Shenoy, S. and Karunasagar, I. (2016) Polymerase Chain Reaction-Restriction Fragment Length Polymorphism (PCR-RFLP) for Rapid Diagnosis of Neonatal Sepsis. Indian Journal of Medical Research, 143, 72-78. http://dx.doi.org/10.4103/0971-5916.178613

[20] Muley, V.A. and Ghadage, D.P. (2015) Bacteriological Profile of Neonatal Septicemia in a Tertiary Care Hospital from Western India., Bhore AV1. Journal of Global Infectious Diseases, 7, 75-77. http://dx.doi.org/10.4103/0974-777X.154444 
[21] Dramowski, A., Madide, A. and Bekker, A. (2015) Neonatal Nosocomial Bloodstream Infections at a Referral Hospital in a Middle-Income Country: Burden, Pathogens, Antimicrobial Resistance and Mortality. Paediatrics and International Child Health, 35, 265-272. http://dx.doi.org/10.1179/2046905515Y.0000000029

[22] Özkan, H., Köksal, N., Çetinkaya, M., Kiliç, Ş., Çelebi, S., Oral, B. and Budak, F. (2012) Serum Mannose-Binding Lectin (MBL) Gene Polymorphism and Low MBL Levels Are Associated with Neonatal Sepsis and Pneumonia. Journal of Perinatology, 32, 210-217. http://dx.doi.org/10.1038/jp.2011.79

[23] Dzwonek, A.B., Neth, O.W., Thiébaut, R., Gulczynska, E., Chilton, M., Hellwig, T., Bajaj-Elliott, M., Hawdon, J. and Klein, N.J. (2008) The Role of Mannose-Lectin Binding in Susceptibility to Infection in Preterm Neonates. Pediatric Research, 63, 680-685. http://dx.doi.org/10.1203/PDR.0b013e31816fdbff

[24] Roy, S., Knox, K., Segal, S., Griffiths, D., Moore, C.E., Welsh, K.I., Smarason, A., Day, N.P., McPheat, W.L., Crook, D.W., Hill, A.V. and Oxford Pneumoccocal Surveillance Group (2002) MBL Genotype and Risk of Invasive Pneumococcal Disease: A Case-Control Study. Lancet, 359, 1569-1573. http://dx.doi.org/10.1016/S0140-6736(02)08516-1

[25] Ahrens, P., Kattner, E., Köhler, B., Härtel, C., Seidenberg, J., Segerer, H., Möller, J., Göpel, W. and Genetic Factors in Neonatology Study Group ( 2004) Mutations of Genes Involved in the Innate Immune System as Predictors of Sepsis in Very Low Birth Weight Infants. Pediatric Research, 55, 652-656. http://dx.doi.org/10.1203/01.PDR.0000112100.61253.85

[26] Auriti, C., Prencipe, G., Inglese, R., Azzari, C., Ronchetti, M.P., Tozzi, A., Seganti, G., Orzalesi, M. and De Benedetti, F. (2010) Role of Mannose-Binding Lectin in Nosocomial Sepsis in Critically Ill Neonates. Human Immunology, 71, 1084-1088. http://dx.doi.org/10.1016/j.humimm.2010.08.012

[27] Frakking, F.N., Brouwer, N., van Eijkelenburg, N.K., Merkus, M.P., Kuijpers, T.W., Offringa, M. and Dolman, K.M. (2007) Low Mannose-Binding Lectin (MBL) Levels in Neonates with Pneumonia and Sepsis. Clinical and Experimental Immunology, 150, 255-262. http://dx.doi.org/10.1111/j.1365-2249.2007.03479.x

[28] Schlapbach, L.J., Mattmann, M., Thiel, S., Boillat, C., Otth, M., Nelle, M., Wagner, B., Jensenius, J.C. and Aebi, C. (2010) Differential Role of the Lectin Pathway of Complement Activation in Susceptibility to Neonatal Sepsis. Clinical Infectious Diseases, 51, 153-162. http://dx.doi.org/10.1086/653531

[29] Jack, D.L., Klein, N.J. and Turner, M.W. (2001) Mannose-Binding Lectin: Targeting the Microbial World for Complement Attack and Opsonophagocytosis. Immunological Reviews, 180, 86-99. http://dx.doi.org/10.1034/j.1600-065X.2001.1800108.x

[30] Pehlivan, M., Sahin, H.H., Ozdilli, K., Onay, H., Ozcan, A., Ozkinay, F. and Pehlivan, S. (2014) Gene Polymorphisms and Febrile Neutropenia in Acute Leukemia-No Association with IL-4, CCR-5, IL-1RA, but the MBL-2, ACE, and TLR-4 Are Associated with the Disease in Turkish Patients: A Preliminary Study. Genetic Testing and Molecular Biomarkers, 18, 474-481. http://dx.doi.org/10.1089/gtmb.2014.0004

[31] Hellemann, D., Larsson, A., Madsen, H.O., Bonde, J., Jarløv, J.O., Wiis, J., Faber, T., Wetterslev, J. and Garred, P. (2007) Heterozygosity of Mannose-Binding Lectin (MBL2) Genotypes Predicts Advantage (Heterosis) in Relation to Fatal Outcome in Intensive Care Patients. Human Molecular Genetics, 16, 3071-3080. http://dx.doi.org/10.1093/hmg/ddm265

[32] Klostergaard, A., Steffensen, R., Møller, J.K., Peterslund, N., Juhl-Christensen, C. and Mølle, I. (2010) Sepsis in Acute Myeloid Leukaemia Patients Receiving High-Dose Chemotherapy: No Impact of Chitotriosidase and Mannose-Binding Lectin Polymorphisms. European Journal of Haematology, 85, 58-64. http://dx.doi.org/10.1111/j.1600-0609.2010.01443.x

[33] Nauta, A.J., Raaschou-Jensen, N., Roos, A., Daha, M.R., Madsen, H.O., Borrias-Essers, M.C., Ryder, L.P., Koch, C. and Garred, P. (2003) Mannose-Binding Lectin Engagement with Late Apoptotic and Necrotic Cells. European Journal of Immunology, 33, 2853-2863. http://dx.doi.org/10.1002/eji.200323888 


\section{Submit or recommend next manuscript to SCIRP and we will provide best service for you:}

Accepting pre-submission inquiries through Email, Facebook, LinkedIn, Twitter, etc.

A wide selection of journals (inclusive of 9 subjects, more than 200 journals)

Providing 24-hour high-quality service

User-friendly online submission system

Fair and swift peer-review system

Efficient typesetting and proofreading procedure

Display of the result of downloads and visits, as well as the number of cited articles

Maximum dissemination of your research work

Submit your manuscript at: http://papersubmission.scirp.org/

Or contact oji@scirp.org 